УДК 336.2 .026

DOI: https://doi.org/10.37320/2415-3583/11.34

Колотуха С.М.

кандидат економічних наук, доцент, Уманський національний університет садівництва ORCID: https://orcid.org/0000-0002-3614-5047

Гвоздєй Н.І.

кандидат економічних наук, доцент, Уманський державний педагогічний університет імені Павла Тичини ORCID: https://orcid.org/0000-0002-7251-7696

\title{
СУЧАСНІ УМОВИ РОЗВИТОКУ ЗЕМЕЛЬНИХ ВІДНОСИН ТА ІПОТЕЧНОГО КРЕДИТУВАННЯ АГРАРНИХ ПІДПРИЕМСТВ
}

У статті досліджено розвиток земельних відносин, запровадження ринку землі сільськогосподарського призначення та іпотечного кредитування сільськогосподарських підприємств у контексті сучасних умов. В Україні обтрунтовано побудову систему іпотечного кредитування, щцо поєднує елементи однорівневої та дворівневої моделей. Доведено, щчо невід 'ємною складовою частиною фінансового обслуговування суб' єктів господарювання в Украӥні повинна стати розгалужена мережа спеціалізованих державних і недержавних іпотечних структур. Центральною ланкою системи земельно-іпотечного кредитування повинен стати Державний акиіонерний земельний (іпотечний) банк. Таким чином, заходи щчодо підвищення ефективності використання земель сільськогосподарського призначення повинні проводитися в комплексі з удосконаленням фінансово-кредитного механізму.

Ключові слова: ринок землі, фінансово-кредитне забезпечення, кредитний механізм, земельні ресурси, земельна реформа, земельно-ресурсний потенціал, земельна іпотека.

Постановка проблеми. Перехід аграрного сектору економіки до ринку потребує подальших рішучих кроків у реформуванні земельних відносин, оскільки незавершеність земельної реформи негативно позначається на ефективності використання сільськогосподарських земель. Нині сільськогосподарське виробництво потребує технічного і технологічного переозброєння, формування інвестиційно привабливого середовища.

Розвиток іпотечних відносин у сільському господарстві в сучасних умовах набуває великого значення у зв'язку з необхідністю залучення додаткових інвестицій в агропромисловий комплекс із метою розвитку сільськогосподарських підприємств. Низька якість іпотечного забезпечення обмежує доступ сільськогосподарських підприємств до кредитних ресурсів і підвищує кредитні ризики банків. У зв' язку з цим становлення земельногоринкує першочерговим завданням, вирішення якого дасть змогу запустити в дію механізм іпотечного кредитування в сільському господарстві, де іпотекою будуть сільськогосподарські угіддя, що сприятиме залученню інвестиційних кредитів.

Проте в умовах ринку і розвитку різних форм господарювання багато аспектів цієї важливої проблеми вимагають подальших поглиблених досліджень із метою пошуку шляхів удосконалення фінансово-кредитного механізму.

Аналіз останніх досліджень і публікацій. Питання фінансово-кредитного забезпечення сільськогосподарських товаровиробників як теоретичного, так і практичного спрямування роз- глядаються у працях багатьох науковців, таких як: В.А. Ясинський [1], М.С. Мартинюк [2], Ю.О. Лупенко [3], Я.М. Гандзало [4], М.К. Гайдай [5], А.Л. Михайлик [6], Н.П. Солов’яненко [7], С.А. Балюк [8], В.А. Голян [13], знані іноземні науковці $[9 ; 10 ; 11]$.

Проте в умовах ринку і розвитку різних форм господарювання багато аспектів цієї важливої проблеми вимагають подальших поглиблених досліджень із метою пошуку шляхів удосконалення фінансово-кредитного механізму.

Метою статті $\epsilon$ дослідження перспектив запровадження цивілізованого ринку земель в Україні та окреслення основних напрямів його державного економіко-правового регулювання, зокрема, посилення ролі фінансових аспектів.

Виклад основного матеріалу. Світовий i набутий вітчизняний досвід показує, що будь-яка реформа в аграрній галузі може забезпечити позитивний результат лише за умови, якщо вона:

- здійснюється на добровільній основі, демократичним шляхом, за участю і в інтересах селян;

- має державну, правову, фінансову, матеріально-технічну, політичну, організаційну і морально-етичну підтримку;

- здійснюється за принципом соціальної справедливості та наявності сприятливого психологічного клімату;

- проводиться одночасно із соціальними перетвореннями на селі;

- здійснюється спеціальними органами - комітетами, комісіями, робочими групами тощо; 
- надає селянам упевненості в стабільності аграрної політики держави, а також законодавчої бази $[1$, с. 56].

Розвиток ринкових відносин веде до формування ринку землі. Під ринком землі розуміється фрагмент економічного простору, сфера дії економічних форм, що забезпечують процеси купівліпродажу, оренди, застави, обміну й успадкування земельних ділянок. Узагальнено ринок землі може характеризуватися як економічна сфера проведення операцій із землею.

Нині фахівцями пропонуються два основні варіанти проведення наступного етапу земельної реформи - запуску ринку землі (табл. 1) [2, с. 2].

Перший варіант передбачає двохетапний запуск ринку землі. На першому етапі, в 2017-2019 рр., на відкритих електронних торгах продається частина земель державної власності, що дає змогу сформувати уяву про ринкову ціну землі в усіх регіонах. Іноземці та юридичні особи до торгів не допускаються. Юридичні особи до торгів не допускаються. На другому етапі ринок відкривається для громадян. Обмеження з купівлі землі в одні руки - 200 га.

Другий варіант передбачає продаж не права власності на землю, а права оренди. При цьому покупець матиме всі права власника - йому будуть доступні і передання в суборенду, і перепродаж права оренди строком на 49 років. Іноземний капітал залишається гравцем на ринку, як і юридичні особи. Обмеження в площах дискутується.

Питання щодо запровадження ринку сільськогосподарських земель в Україні та його наслідків для іiї економіки, з огляду на сучасний стан розвитку українського села, вимагають застосовувати як вітчизняний, так і зарубіжний досвід.

За результатами дослідження експерти дійшли висновку: чим більш закритий ринок землі, тим менша ціна на неї $[3 ; 4 ; 5]$. Натомість у розвинутих країнах із відкритим земельним ринком зрос-

Таблиця 1 - Економічний і соціальний ефект земельної реформи залежно від вибраної моделі

\begin{tabular}{|c|c|c|}
\hline & $\begin{array}{c}\text { Базова модель: } \\
\text { запуск ринку землі у два етапи } \\
\end{array}$ & \begin{tabular}{|c|} 
Базова модель: \\
продаж права оренди (емфітевзис)
\end{tabular} \\
\hline \multicolumn{3}{|c|}{ Обсяг ринку (поточні показники) } \\
\hline $\begin{array}{l}\text { Площа приватних сільгоспземель } \\
\text { у власності /оренді }\end{array}$ & $\begin{array}{l}\text { 27,7 млн га, які належать } \\
\text { 6,9 млн громадян }\end{array}$ & $\begin{array}{l}\text { 4,7 млн договорів оренди паїв на } \\
\text { загальну площу 16,6 млн га }\end{array}$ \\
\hline $\begin{array}{l}\text { Площа державних сільгоспземель } \\
\text { у власності / оренді }\end{array}$ & 10 млн га & $\begin{array}{l}56 \text { тис. договорів оренди на загальну } \\
\text { площу } 2,5 \text { млн га }\end{array}$ \\
\hline $\begin{array}{l}\text { Відумерла спадщина - офіційні } \\
\text { дані (згідно з даними проекту } \\
\text { Світового банку «Моніторинг } \\
\text { земельних відносин в Україні») }\end{array}$ & $\begin{array}{l}9650 \text { ділянок загальною площею } \\
35802 \text { га }\end{array}$ & $\begin{array}{l}4342 \text { ділянки загальною площею } \\
16,11 \text { тис га (45\% від загальної } \\
\text { кількості) }\end{array}$ \\
\hline $\begin{array}{l}\text { Відумерла спадщина - оцінка } \\
\text { (згідно з даними проекту Світового } \\
\text { банку «Моніторинг земельних } \\
\text { відносин в Україні») }\end{array}$ & $\begin{array}{l}\text { 0,5-1 млн ділянок загальною } \\
\text { площею 1,83-3,7 млн га }\end{array}$ & н/д \\
\hline \multicolumn{3}{|c|}{ Прогнозовані показники } \\
\hline \multirow[t]{2}{*}{ Мінімальна ціна, 1 га } & $\$ 1100$ & 800 \\
\hline & $\begin{array}{l}25 \% \text { в 1-3 рр., 8-10\% в 4-11 } \\
\text { рр. після запуску ринку (згідно } \\
\text { з розрахунками про зміну } \\
\text { ціни на сільгоспугіддя після } \\
\text { встановлення вільного ринку землі } \\
\text { у прибалтійських країнах, країнах } \\
\text { Центральної Свропи, Балканського } \\
\text { півострова). }\end{array}$ & н/д \\
\hline Іпотечне кредитування & + & + \\
\hline Іноземний капітал & - & + \\
\hline Юридичні особи & - & + \\
\hline \multicolumn{3}{|c|}{ Прогнозований ріст врожайності } \\
\hline $\begin{array}{l}\text { Ефект для агровиробництва (ріст } \\
\text { врожайності на кінець першого } \\
\text { етапу) }\end{array}$ & $\begin{array}{l}\text { Зернових за два роки - 31,3\% } \\
\text { (прогноз базується на середньому } \\
\text { зростанні врожайності у згаданих } \\
\text { вище країнах після встановлення } \\
\text { вільного ринку землі) }\end{array}$ & Збереження статусу-кво \\
\hline Ефект для агрохолдингів & $\begin{array}{l}\text { Зростання конкуренції з боку } \\
\text { фермерських господарств }\end{array}$ & Збереження статусу-кво \\
\hline
\end{tabular}


тає вартість не лише купівлі, а й оренди земельних ділянок, яка сягає 250-700 доларів за гектар. Країни з повністю відкритим ринком землі є найбільш успішними, у них більше ВВП на душу населення, більша додана вартість в агросекторі, більша ціна на землю. Прогнозуються 4 варіанти розвитку ситуації із земельним ринком в Україні у наступні 10 років. За умови продовження мораторію з усіма обмеженнями, включаючи відсутність можливості передачі прав власності, Україна отримає понад 30 млрд дол. від приросту ВВП (26 млрд дол.) та додаткових податків. Натомість, якщо мораторій відмінять, але доступ іноземців до ринку землі буде обмеженим, економічний ефект від відкритого ринку 3 певними кількісними чи ціновими обмеженнями передбачається у 81 млрд дол. А запровадження повністю відкритого вільного ринку землі, ймовірно, надасть Україні до 122 млрд дол. через приріст ВВП (83 млрд), інвестицій (32 млрд) та додаткових податків [6, с. 10].

Україна володіє значним земельно-ресурсним потенціалом. Станом на 01.01.2018 року (за даними Держгеокадастру) в Україні налічується 42,7 млн га сільськогосподарських земель, у тому числі 41,5 га сільськогосподарських угідь, природних кормових угідь - 7,8 млн га, земель під забудовою - 2,5 млн га (табл. 2) [1, с. 19].

У сучасних умовах особливо гостро стоїть питання ефективного використання земельних ресурсів та збереження родючості грунтів. Нині сільгоспугіддя України щороку втрачають близько 600 млн тонн грунту та 16 млрд м ${ }^{3}$ поверхневої води, котрої вистачило би для формування 16 млн тонн зерна.

Площа деградованих грунтів з року в рік збільшується на 80 тис. га. Майже кожний третій гектар $(30,7 \%)$ - еродований. Землі, що зазнали руй- нівної дії води та вітру у Луганській, Донецькій, Кіровоградській і Чернівецькій областях, становлять 50-65\% орних площ. У степовій зоні дві третини землі мають знижену родючість. Кожний четвертий гектар - кислий, а в зонах Лісостепу i Полісся - майже кожний другий (49,7-47,4\%). Особливо великі площі $(52,1-65,0 \%)$ кислих грунтів у Вінницькій, Черкаській, Тернопільській і Хмельницькій областях [7, с. 27].

У більшості північноамериканських і європейських країн опрацьовані і підтримуються методи раціонального землекористування, що включають:

- періодичне суцільне великомасштабне i детальне грунтове обстеження (в США протягом $\mathrm{XX}$ століття обстеження проведено чотири рази, і нині проводиться детальне обстеження, в Україні таке обстеження проведено у 1957-1961рр.);

- обов'язкове субсидування аграрного сектору, бо за ринкових умов фермер не в змозі впроваджувати новітні грунтозбережувальні технології, ефективно господарювати і підтримувати родючість грунтів. Але неодмінна умова отримання фермером субсидій - відсутність будь-яких порушень агротехнологій;

- сприяння впровадженню новітніх грунтозбережувальних технологій [ 8, с. 15].

Виходячи з цього, експерти пропонують таку схему фінансування відтворення та охорони земельних ресурсів (рис. 1) [9; 10;11;12].

Одними 3 важливих кроків на шляху вирішення цих проблем є створення Державного акціонерного земельного (іпотечного) банку з відповідною мережею банків у регіонах, який повинен надавати підприємствам аграрного сектору економіки такі види банківських послуг, як:

- інвестиційне i кредитне обслуговування товаровиробників агропромислового комплексу,

Таблиця 2 - Земельний фонд України та його зміни 31990 року

\begin{tabular}{|c|c|c|c|c|c|c|c|c|c|}
\hline \multirow[t]{2}{*}{$\begin{array}{c}\text { Види основних } \\
\text { земельних угідь }\end{array}$} & \multicolumn{8}{|c|}{$\begin{array}{c}\text { Площа земель на початку року, } \\
\text { тис. га }\end{array}$} & \multirow{2}{*}{$\begin{array}{c}\text { Зміни } \\
\text { за період } \\
1990- \\
2018 \text { pp. } \\
(+,-) \\
\end{array}$} \\
\hline & 1990* & $\%$ & 2000 & $\%$ & 2010 & $\%$ & 2018 & $\%$ & \\
\hline Землі сільгосппризначення & 43634,5 & 72,3 & 43057,8 & 71,3 & 42813,7 & 70,9 & 42726,4 & 70,8 & $-908,1$ \\
\hline у т.ч. сільгоспугіддя & 42030,3 & 69,6 & 41827,0 & 69,3 & 41596 & 68,9 & 41507,9 & 68,8 & $-522,4$ \\
\hline з них : рілля & 33570,8 & 55,6 & 32563,6 & 54,0 & 32478 & 53,8 & 32541,3 & 53,9 & $-1029,5$ \\
\hline багаторічні насадження & 1058,0 & 1,8 & 931,9 & 1,5 & 897,7 & 1,5 & 892,4 & 1,5 & $-165,6$ \\
\hline природні кормові угіддя & 7396,5 & 12,3 & 7909,9 & 13,1 & 7899,5 & 13,1 & 7840,5 & 13,0 & 444,0 \\
\hline перелоги & 5,0 & 0,01 & 421,6 & 0,7 & 320,8 & 0,5 & 233,7 & 0,4 & 228,7 \\
\hline Інші сільгоспземлі & 1604,2 & 2,7 & 1230,8 & 2,0 & 1217,3 & 2,0 & 1218,5 & 2,0 & $-385,7$ \\
\hline Ліси та інші лісовкриті площі & 10221,5 & 16,9 & 10413,6 & 17,3 & 10591,9 & 17,5 & 10633,1 & 17,6 & 411,6 \\
\hline Забудовані землі & 566,6 & 0,9 & 2456,2 & 4,1 & 2499,1 & 4,1 & 2552,9 & 4,2 & 1986,3 \\
\hline Інші землі & 4328,2 & 7,2 & 4427,2 & 7,3 & 4450,1 & 7,4 & 4442,5 & 7,4 & 114,3 \\
\hline Разом( територія ) & 60355,0 & 100 & 60354,8 & 100 & 60354,8 & 100 & 60354,9 & 100 & $-0,1$ \\
\hline
\end{tabular}


в тому числі іпотечне кредитування сільськогосподарських товаровиробників під заставу земельних ділянок та майна;

- викуп заставленого неплатоспроможними боржниками майна і землі у комерційних банків;

- довірче управління майном і землею та коштами неплатоспроможних підприємств АПК;

- здійснення лізингових та факторингових операцій для сільськогосподарських товаровиробників;

- страхування майна, життя та фінансових ризиків у сільській місцевості;

- здійснення комісійних операцій із товарами, майном та землею;

- надання послуг із ведення обліку, аудиту й аналізу діяльності підприємств та розроблення інвестиційних планів і бізнес-проектів;
- здійснення обслуговування зовнішньоекономічних операцій товаровиробників агропромислового комплексу;

- здійснення інших банківських операцій;

- виконання функцій методичного центру 3 надання консультаційних послуг підприємствам агропромислового комплексу, кредитним спілкам.

Таким чином, пропонується така модель системи іпотечного кредитування під заставу землі (рис. 2).

Важливим інструментом, що забезпечить легітимність заставних операцій, є також створення Української державної земельної біржі, яка повинна стати постійно діючим земельним ринком і комерційним посередником, що буде сприяти укладенню угод, операцій із землею, а також об'єднувати і контролювати діяльність регіональних земельних бірж.

НАПРЯМИ ТА ДЖЕРЕЛА ФІНАНСУВАННЯ ВІДТВОРЕННЯ Й ОХОРОНИ ЗЕМЕЛЬНИХ РЕСУРСІВ

\begin{tabular}{|l|l|l|l|}
\hline & \multicolumn{2}{|c|}{ Джерела фінансування } \\
\hline \multirow{2}{*}{\begin{tabular}{|l|l|l|}
\hline Державний \\
бюджет
\end{tabular}} & $\begin{array}{l}\text { Місцеві } \\
\text { бюджети }\end{array}$ & $\begin{array}{l}\text { Кошти, отримані в рамках міжнародної } \\
\text { технічної допомоги та виконання вимог } \\
\text { глобальнихприродоохороннихконвенцій }\end{array}$ & $\begin{array}{c}\text { Власні кошти підприємств- } \\
\text { землекористувачів та } \\
\text { домогосподарств-землристувачів }\end{array}$ \\
\hline
\end{tabular}

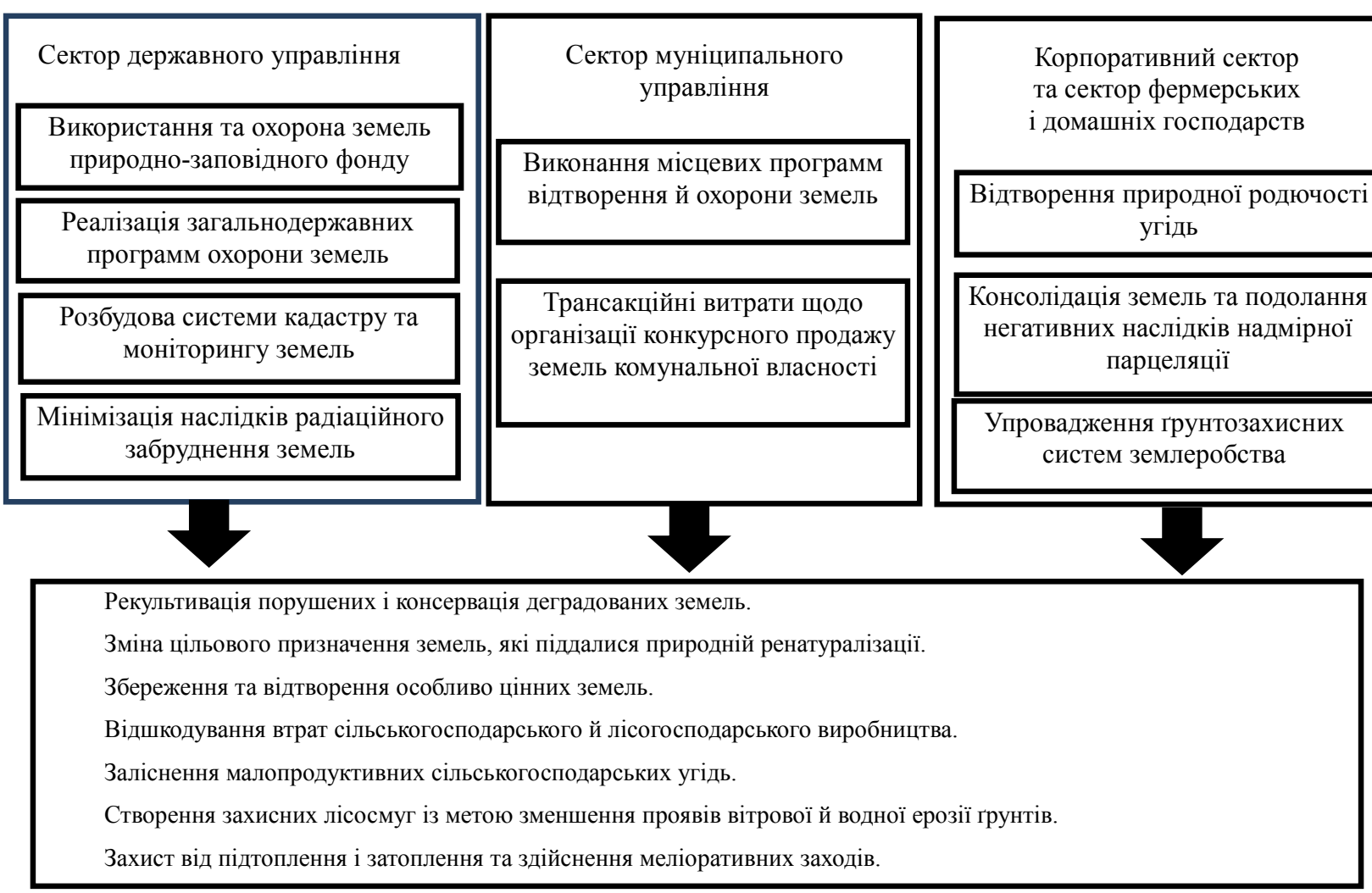

Рисунок 1 - Фінансування відтворення та охорони земельних ресурсів у розрізі основних секторів землекористувачів [13, с. 86; 17] 


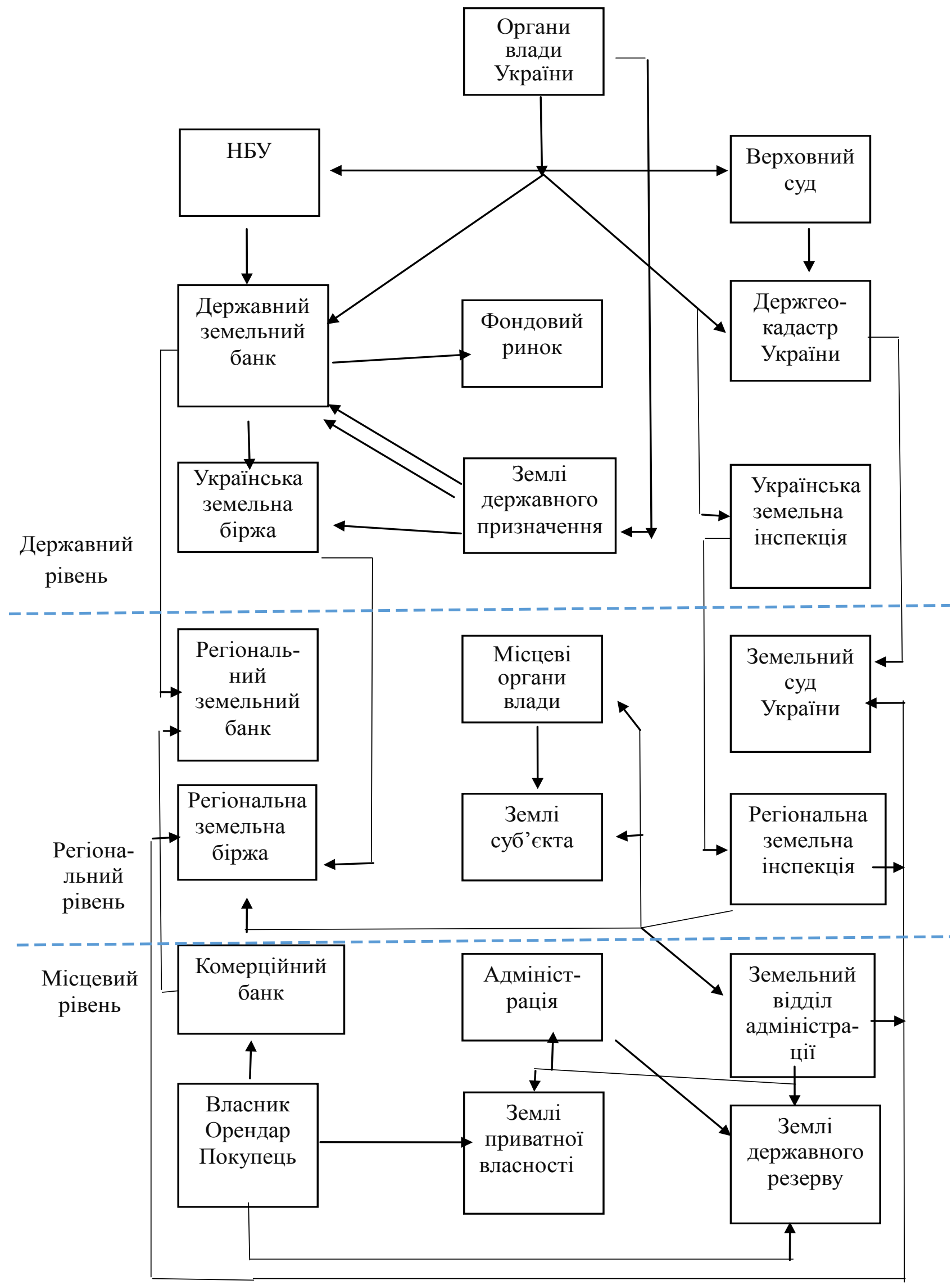

Рисунок 2 - Модель системи іпотечного кредитування під заставу землі в Україні Джерело: сформовано авторами 
Крім цього, вимагають негайного вирішення правові земельні питання. Оскільки чинна судова система не може кваліфіковано і в оптимальні терміни вирішити питання власності на землю, меж земельних ділянок, показників їхньої оцінки, розмірів ставок земельних платежів, розподілу земельних учасників, назріла необхідність організації у структурі судових інстанцій Земельного господарського суду України з відповідними регіональними судами.

Створення і діяльність земельної кредитної системи неможливі також без відповідної Земельної інспекції, що буде здійснювати інспекторську діяльність за дотриманням земельного законодавства й угод.

Висновки. Підсумовуючи результати проведеного дослідження, зазначимо, що ринок земель сільськогосподарського призначення в Україні - питання найближчої перспективи. Поряд із цим для запровадження цивілізованого ринку сільськогосподарських угідь державі необхідно вирішити цілу низку проблем, пов'язаних із правовим забезпеченням зазначеного сегменту ринку та фінансовим забезпеченням його запровадження. За умови відміни мораторію на продаж сільськогосподарських угідь в Україні за обмеження доступу до вітчизняного земельного ринку іноземців передбачається економічний ефект у розмірі 68 млрд дол. США. 3 них 9,4 млрд дол. припадає на прогнозовані інвестиції. Запровадження повністю відкритого вільного ринку землі надасть Україні до 122 млрд дол. США через приріст ВВП (83 млрд), інвестицій (32 млрд) та додаткових податків.

Доведено, що ефективність упровадження системи фінансово-економічних складників відповідного механізму забезпечення збалансованого землекористування у сфері агровиробництва потребує запровадження ринкового обігу земельних ділянок сільськогосподарського призначення. Відзначено, що за умов запровадження ринку сільськогосподарських земель земля стає не лише фактором виробництва, а й рушійною силою економічного розвитку за рахунок впливу на формування системи фінансово-економічних відносин та системи земельно-іпотечного кредитування.

\section{Список використаних джерел:}

1. Ясинський В.А. Землетворець. Землевпорядний вісник. 2011. № 6. С. 56.

2. Мартинюк М.С. Ринок землі: який шлях вибрати? Землевпорядний вісник. 2016. № 7. С. 2-3.

3. Лупенко Ю.О., Ходаківська О.В. Наукові засади запровадження ринкового обігу земель сільськогосподарського призначення. Економіка АПК. 2016. № 12. С. 5-15.

4. Гадзало Я.М., Лузан Ю.Я. Земельна реформа: проблеми і перспективи розвитку аграрної економіки. Економіка АПК. 2017. № 1. С. 5-14.

5. Гайдай М.К. Як працює ринок землі за кордоном? Землевпорядний вісник. 2016. № 6. С. 39

6. Михайлик А.Л. Прихильники і противники мораторію шукають аргументи ... Землевпорядний вісник. 2016 №11. С. $3-10$.

7. Солов'яненко Н.П. Нормативна грошова оцінка земель сільськогосподарського землекорстування. Землевпорядний вісник. 2016. № 11. С. 27.

8. Балюк С.А. Ми повинні залишити нащадкам родючий грунт, а не пустелю. Землевпорядний вісник. 2017. № 2, С. 15.

9. Ahner D. (2004). Rural Development policy in an enlarged European Union. Proposals of the European Commission for the period 2007-2013. Halle, Germany. November, 5, 15 p.

10. Bird R. (1974). Taxing agricultural land in developing countries . Cambridge: Harvard University Press, p. 361.

11. Ciaian P. d'Artis Kancs, J. Swinnen, K. Herck, L. Vranken. (2012). Institutional Factors Affecting Agricultural Land Markets. Brussels: Centre for European Policy Studies. p. 22. (дата звернення: 23.04.2020).

12. Johan Swinnen. Pavel Ciaian, d'Artis Kancs. (2009). Study on the Functioning of Land Markets in the EU Member States. Centre for European Policy Studies, Place du Congres 1, B.1000 Brussels. (дата звернення: 23.04.2020).

13. Голян В.А., Третяк Т.А. Фінансування відтворення та інституціональні передумови. Фінанси України. 2016. № 12 C. 77-91.

\section{References:}

1. Yasinsky V.A.( 2011). Land Management Bulletin. No. 6. P. 16.

2. Martyniuk M. S. (2016). Market of the earth: which way to choose? Land Management Gazette. № 7. P. $2-3$.

3. Lupenko, Yu.O. (2016). № 12. p. 5-15.

4. Gadzalo Ya. M., Luzan Yu. Ya. (2017). Zemelna reform: problems and prospects for development of agrarian economics. Ekonomika APK. № 1. p. 5-14.

5. Gaidai M.K.(2016). Yak praksyu rinok earth beyond the cordon? Land dispatch system. № 6. P. 39.

6. Mikhailik A.L. (2016). The supporters and opponents of the moratorium are looking for arguments ... Land Management Gazette. No. 11. P. 3-10.

7. Solovyanenko N.P. (2016). Normative monetary valuation of agricultural land plots. Land Management Gazette No. 11. P. 27

8. Balyuk S.A. (2017). We must leave the descendants fertile soil, not the desert. Land Planning Bulletin No. 2. P. 15.

9. Ahner D. (2004). Rural Development policy in an enlarged European Union. Proposals of the European Commission for the period 2007-2013. Halle, Germany. November. 5. 15 p.

10. Bird R. (1974). Taxing agricultural land in developing countries. Cambridge: Harvard University Press. 361 p. 
11. Ciaian P., d'Artis Kancs, J. Swinnen, K. Herck. (2012). Vranken Institutional Factors Affecting Agricultural Land Markets. Brussels.: Centre for European Policy Studies. 22 p. (accessed 23 April 2020).

12. Johan Swinnen., Pavel Ciaian, d'Artis Kancs. (2009). Study on the Functioning of Land Markets in the EU Member States. Centre for European Policy Studies, Place du Congres 1. B.1000 Brussels. (accessed 23 April 2020).

13. Golyan V.A., Tretiak T. A. (2016). Financing of reproduction and institutional conditions. Finances of Ukraine. No. 12 P. 77-91.

\author{
Kolotukha Sergiy \\ Uman National University of Horticulture \\ Gvozdej Nataliia
}

Uman State Pedagogical University Pavlo Tychyna

\title{
CURRENT CONDITIONS DEVELOPMENT OF LAND RELATIONS AND MORTGAGE LOANS OF AGRICULTURAL ENTERPRISES
}

The urgency of the research topic is directed at the development of land relations, the introduction of agricultural land market and mortgage lending to agricultural enterprises in the context of modern conditions. In Ukraine, the construction of a system of mortgage lending, which combines elements of one-level and two-level models, is substantiated. The process of market turnover of land assets in the agricultural sector of the economy, a special role belongs to the organized system of mortgage lending. In this regard, after the lifting of the moratorium on the alienation of agricultural land, the institute of land mortgage should take one of the central places in the financing system of the agricultural sector. This raises the importance of the development of the theoretical and methodological foundations for the formation of an effective system of land-mortgage lending and regulation of the market turnover of land assets in agriculture. The methodological basis of the research is the assumption of mutual determinism of economic processes, which is realized in the synthesis of analytical achievements of various areas of economic research. On this basis, applied methods and approaches of classical economic theory, the theory of land rent, the theory of value and consumer behavior regarding the market turnover of land assets through the mortgage mechanism, in particular the system approach, the method of analysis and synthesis, design and calculated and experimental. The features of credit relationships between banks and farms, are defined and analyzed the trend in the current state of lending industry. Analysis of the financial stability of banks was conducted and the integral indicator of credit risk on the basis of scoring was calculated. Proposals for the development of credit relations between domestic agricultural enterprises and banks on the basis of positive foreign experience credit for agricultural enterprises were made. Systematized a number of proposals for the implementation of mortgage of land relations on the basis of an objective assessment of the land value, a mechanism of land transfer by landowners as collateral is described. It is proved that an extensive network of specialized state and non-state mortgage structures should be an integral part of the financial services of business entities in Ukraine. The central shareholder of the land-mortgage lending system should be the State Stock Land (Mortgage) Bank. Thus, measures to improve the use of agricultural land should be carried out in conjunction with the improvement of the financial and credit mechanism.

Key words: land market, financial and credit policy, credit mechanism, land resources, land reform, land resource potential, land mortgage.

JEL classification: G21, H81, E21, P45. 